\title{
A.В. Черкасов
}

\section{Д.А. КРАЙНОВ КАК ИССЛЕДОВАТЕЛЬ КАМЕННОГО ВЕКА КРЫМА}

\begin{abstract}
Представлен историографический анализ творческого наследия ученого, археолога Д.А. Крайнова (1904-1998) по исследованию первобытной истории Крымского полуострова в контексте выделенных двух периодов. Первый - полевой (1935-1941 годы), характерными содержательными особенностями которого стали открытие в горной и предгорной части полуострова серии первобытных стоянок. Второй период - академический (1955-1957 годы), знаменующийся систематизацией археологического материала и анализом коллекций, собранных в довоенный период; изданием научных монографий и серии публикаций по крымской тематике (в том числе посвященных стоянкам Таш-Аир I, II и Замиль-Коба I, II); созданием авторской периодизации крымских памятников доисторического периода.

Ключевые слова: первобытная история Крыма; периодизация первобытной культуры, первобытного поселения; археологический памятник; историография изучения каменного века, личности ученого; историческое краеведение.
\end{abstract}

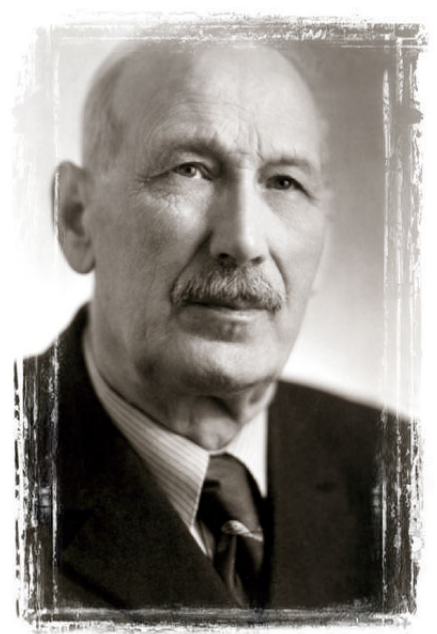

В современной отечественной историографии накоплен значительный опыт тематических обзоров по истории каменного века Крыма, нашедший отражение в начальных главах научных публикаций. Однако, ссылаясь на предшественников в изучении древних памятников, современные авторы часто формально относятся к биографиям и творческой деятельности тех ученых, которые находились у истоков открытий. А между тем именно они, иногда в довольно трудных социокультурных условиях, находили возможности совершать эти открытия, заботиться о сохранении уже известных памятников прошлого Крыма, чтобы не прерывалась многолетняя эстафета исторического изучения полуострова как неотъемлемой части России.

Среди таких ученых отдельную позицию занимает личность археолога, доктора исторических наук Дмитрия Александровича Крайнова. При этом следует отметить, что основная часть изданных публикаций, посвященных ученому, обычно рассматривает его биографию и этапы деятельности или в контексте общего развития отечественной археологической науки (работы А.А. Формозова, Г.С. Лебедева, Л.В. Клейна), или ориентируясь на исследования археолога в центральной части Русской равнины (публикации А.В. Уткина, Е.В. Костылевой и др.). Таким образом, крымский период творчества Д.А. Крайнова остается на определенной периферии историографического анализа. Предлагаемая публикация призвана частично восполнить этот пробел.

Дмитрий Александрович Крайнов родился 30 сентября 1904 г. в деревне Ивашево Александровского уезда Владимирской губернии. Укажем на условность отмеченной даты рождения по причине как сложных социально-исторических реалий в стране в начале $\mathrm{XX} \mathrm{в.,} \mathrm{так} \mathrm{и} \mathrm{особенностей} \mathrm{состава} \mathrm{семьи} \mathrm{Крайновых} \mathrm{(у}$ родителей Дмитрия - крестьян среднего достатка, было 18 детей). В 1916 г. Д.А. Крайнов был зачислен семинаристом в духовное училище Переславля-Залесского, но после событий 1917 г. вернулся на родину, где окончил курс среднего образования в Киржачской мужской гимназии. В 1925 г. Д.А. Крайнов поступил на этнологический факультет историко-археологического отделения Первого МГУ. Здесь постепенно сферой научных интересов молодого человека становятся проблемы отечественной первобытной археологии. Под руководством профессоров Василия Алексеевича Городцова и Александра Яковлевича Брюсова Дмитрий Александрович принимает активное участие в археологических экспедициях в Московской и Брянской областях, Карелии и Летнего берега Белого моря. В 1928 г. в печатном сборнике университетского научно-археологического кружка публикуется его первая авторская статья «Стоянка Усть-Яренга». Всего же за продолжительную научную деятельность ученым было издано более 300 работ, в том числе 6 монографий [1. С. 97].

С 1929 г., после окончания университета, и до начала Великой Отечественной войны Д.А. Крайнов работал последовательно научным сотрудником, ученым секретарем, а затем директором Государственного музея «Александровская Слобода» (филиал Государственного исторического музея (далее ГИМ)). Параллельно основной деятельности учился в Московском музыкальном училище имени М.M. ИпполитоваИванова, по окончании которого в 1937 г., получив звание оперного певца, выступал в Московском Театре художественной самодеятельности. В этот период археологом организуются и проводятся экспедиции на территории Успенского монастыря в Александрове, изучаются остатки дворцовых построек Ивана IV Грозного; раскапываются фатьяновские грунтовые могильники эпохи бронзы в Ярославской и Московской областях (Вауловский, Верейский, Сущевский и др.), в 
научном содружестве с В.А. Городцовым продолжаются исследования Тимоновской палеолитической стоянки в Брянской области [2].

К 1934-1940 гг. относится и первый «крымский период» первобытных исследований Дмитрия Александровича. Так, с 1935 г. ГИМ под непосредственным руководством Д.А. Крайнова приступает к планомерному обследованию археологических памятников времени палеолита и неолита на полуострове. За шесть лет экспедиционно-исследовательских работ сотрудниками было открыто более 20 стоянок, среди которых были знаковые объекты - Таш-Аир I, II, Замиль-Коба I, II, характеризующиеся наличием мощных культурных напластований от мадленской стадии верхнего палеолита до средневекового времени. Частичное подтверждение получило авторское предположение о наличии на верхнепалеолитических стоянках Крыма остатков неандертальского человека. На полуострове были обнаружены первые в регионе погребенные стоянки мустьерской эпохи [3. С. 23]. На последнем факте следует остановиться детальнее

В 30-х - начале 40-х гг. ХХ в. отечественный ученый Сергей Николаевич Замятнин объяснял незначительное количество выявленных памятников каменного века тем, что большинство из них находилось в так называемом погребённом состоянии, перекрытыми обвалившимися со временем сдвигами, осыпями, обломками скальных сводов [4]. В 1940 г. Д.А. Крайнов в Крыму подтвердил гипотезу С.Н. Замятнина. Исследователем была найдена такая стоянка, локализированная на северной скальной стенке Бахчисарайской балки, напротив ущелья Майрам-дере на высоте 33-36 м над уровнем р. Чурук-су и в 80 м по склону от русла указанной реки. Стоянка получила название Бахчисарайской. Разведочный шурф установил наличие культурных отложений, а в дальнейшем позволил сделать вывод о двуслойности нового местонахождения [5. C. 144]. Так, в верхнем слое собрали 118 изделий из кремня, нижний - презентовал коллекцию из 1800 артефактов, реликтовые остеологические остатки. Д.А. Крайнов допустил, что место постоянного пребывания обитателей стоянки располагалось примерно в 15 м к северу от шурфа, среди нагромождения скал следствия обвала козырька навеса. В дальнейшем новым шурфом, севернее массива обвала, под самой скалой, была локализирована часть входа в древнюю пещеру. Археологам удалось рассмотреть достаточно просторную камеру размерами 9 на 4 м с предполагаемыми человеческими костями у входа. К сожалению, проникнуть в пещеру помешали глыбы завала [6. С. 78], и исследование Бахчисарайской стоянки возобновилось уже после окончания Великой Отечественной войны в 1957 г. экспедицией под руководством А.А. Формозова.

Результаты исследования Бахчисарайской стоянки были отражены Д.А. Крайновым в экспедиционных отчетах и позже обобщены в серии научных публика- ций, где отмечалось научное значение погребённой пещеры, состоявшее не только в локализации подобного типа первобытных памятников на территории Крыма, но и в предоставлении археологических материалов, необходимых для целостной характеристики эпохи палеолита всего региона. Кроме этого, Д.А. Крайновым были конкретизированы характерные особенности первобытных памятников Крыма (наличие значительного количества камней в гротах и навесах; смывы и сдвиги почвы; неровности рабочих площадок; многослойность и неодинаковая мощность культурных наслоений в середине навеса и на площадках), сформулированы основные принципы методики их раскопок, не потерявшие актуальности и в современных условиях. К примеру, проведение раскопок сравнительно небольшими квадратами послойно с сохранением между ними контрольных перемычек; детализированное описание каждого найденного артефакта с дальнейшей интерпретацией и типологизацией и др. [7].

В июле 1941 г. Д.А. Крайнов записался добровольцем в Ленинскую дивизию Московского народного ополчения, однако уже в октябре 1941 г. под Вязьмой попал в окружение и до июля 1943 г. находился на оккупированных территориях. После освобождения Дмитрий Александрович остался на фронте, но в мае 1944 г. был осужден по статье 58 (1б) и приговорен к десяти годам исправительно-трудовых лагерей. После досрочного освобождения в 1951 г. он вернулся на родину, некоторое время работал руководителем художественной самодеятельности в клубе текстильной фабрики «Свобода» в поселке Горка станции Бельково (Киржачский район), а в 1954 г. по ходатайствам археолога Александра Яковлевича Брюсова и антрополога Михаила Михайловича Герасимова Д.А. Крайнов устроился на должность старшего научного сотрудника в Угличском краеведческом музее [2].

В 1955 г. ученый был зачислен в штат Института археологии РАН младшим научным сотрудником. С этим событием биографии связан второй «крымский период» научных исследований ученого. В 1957 г. продолжилось исследование Бахчисарайской пещерной стоянки, на своих довоенных материалах была защищена кандидатская диссертация на тему «Пещерная стоянка Таш-Аир І».

Первобытный памятник Таш-Аир I, содержащий не только разновременные культурные наслоения (10 горизонтов), но и произведения древнейшего искусства, была обнаружена Д.А. Крайновым в 1935 г. Раскопки стоянки и изучение наскальной живописи продолжались на протяжении полевых сезонов 1936-1940 гг. при участии известных ученых С.Н. Замятнина, П.П. Бабенчикова, М.Д. Воскресенского, Г.В. Ильина и др. Изображения, выполненные минеральной краской красно-бурого цвета на особенном жировом составе, располагаются в восточной части навеса на высоте около 2 м над современной поверхностью площадки. Д.А. Крайновым было установлено, что значительная 
часть творений первобытного человека в восточной части стены уничтожено в результате каменоломных работ, проведенных в 1934 г. при строительстве дороги. В то же время факт обнаружения в тавро-скифском слое фрагментов рисунков, а также данные Крымской сейсмологической станции о катастрофическом землетрясении V-IV тыс. до н.э. свидетельствовали, что постепенное разрушение памятника началось еще с древнейших времён [8. С. 10].

Проведенный в дальнейшем сравнительный анализ изображений Таш-Аира со скифо-сарматскими рисунками Неаполя Скифского и Керченского полуострова, а также содержательное изучение фигур и находки в энеолитических слоях кусочков минеральной краски и окрашенных в красный цвет галек позволили Д.А. Крайнову уточнить хронологический период их создания (VI-II тыс. до н.э., эпоха ямно-катакомбной культуры), тем самым скорректировав гипотезу П.Н. Шульца про отнесение таш-аирской живописи к эпохе раннего железного века [9].

Д.А. Крайнов установил единовременность нанесения рисунков на скальный свод. Этот факт обусловливался такими авторскими наблюдениями:

- расположение фигур на одинаковом уровне над современной поверхностью;

- наличие общего фриза всей композиции;

- идентичность краски нанесения;

- отсутствие среди изображений рисунков, перекрывающих другие, замазанных мест и т.п.;

- покрытие всех изображений одинаковой коркой («загаром»);

- идентичность техники изображения человеческих фигур (в частности, использование силуэтного, а не контурного стиля).

Анализ остеологического материала стоянки ТашАир II позволил Д.А. Крайнову актуализировать и авторски рассмотреть проблему генезиса в Крыму основных видов домашних животных, предоставить обобщенную характеристику начальных стадий развития животноводства на полуострове. Так, исследователь считал, что уже в мезолите крымский человек сумел доместицировать все известные виды домашних животных, за исключением лошади и осла. Тем самым было сформулировано предположение о возникновении в мезолитическое время объективных и субъективные предпосылок перехода к производящему хозяйству [8. С. 121-138].

Материал неолитического слоя Таш-Аира, по мнению ученого, свидетельствовал, что в этот период в хозяйстве первобытного человека получила применение примитивная остродонная керамика, ножи и «серпы» с вкладышами, т.е. сложились основы земледелия. Человеком был доместицирован крупный и мелкий рогатый скот. Таким образом, подытоживал Д.А. Крайнов, в развитом неолите (для Крыма это IV-III тысячелетия до н. э.) животноводство, в том числе и отгонное на горные пастбища-яйлы, в совокупности с мотыж- ным земледелием постепенно становятся приоритетными [8. С. 139], а в эпоху энеолита и ранней бронзы (III-II тысячелетия до н.э.) заняли ведущие позиции в хозяйстве [Там же. С. 140].

В целом, по итогам многолетнего изучения ТашАирского комплекса ученым были высказаны и аргументированы следующие идеи:

- уникальности памятника, содержащего десять культурных слоёв от палеолита до позднего Средневековья;

- его эталонности для создания периодизации послепалеолитических культур Крыма (в частности, прослеживания последовательности эволюции форм кремневых орудий и техники их выработки). При этом ученым был апробирован сравнительный метод с привлечением данных многослойной стоянки Замиль-Коба II и материалов стоянок Среднего Поднепровья, Подонья и Нижнего Поволжья);

- логической связи верхнего слоя стоянки Сюрень II (исследователи - Г.А. Бонч-Осмоловский, Е.А. Векилова) и ранних азильских комплексов стоянки ТашАир II, Качинского навеса и грота Буран-Кая. В этом контексте Д.А. Крайнов стремился заполнить лакуну, существующую в изучении палеолита Крыма. Кроме этого, из общей массы так называемых позднетарденуазских стоянок Д.А. Крайновым была выделена раннепалеолитическая и впервые охарактеризована поздняя стадия неолита.

Сама же авторская периодизация послепалеолитических культур Крыма, разработанная на основе материалов Таш-Аира, состояла из следующих хронологических, качественно отличающихся этапов:

- конец позднего палеолита - улучшение климатических условий на полуострове, появление новых форм ведения хозяйства, микролитизация орудий и усовершенствование производства пластинок [Там же. С. 141];

- ранняя стадия мезолита (азильское время) - установление современной геологической эпохи; двойной

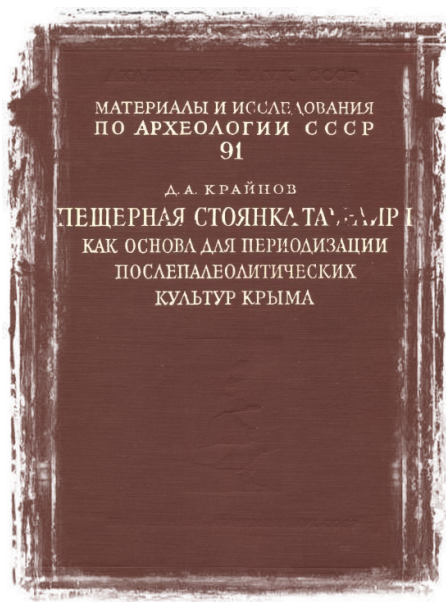
характер формы кремневых орудий и техники их изготовления (палеолитический и мезолитический); совершенствование способов охоты, попытки доместикации дикой свиньи;

- поздний мезолит - демографический рост населения полуострова; распространение микроиндустрии и техники вкладышей, стандартизация форм орудий, особенно геометрических микролитов, доместикация крупного рогатого скота, пропедевтика животноводства и земледелия [Там же. С. 142]; 
- ранний неолит (на раннем этапе характерно наличие позднетарденуазских стоянок без керамики, на позднем - стоянок с керамикой, украшенной нарезным орнаментом) - развитие микроиндустрии, отжимной струйной техники с нанесением ретуши; появление первых орудий с двусторонней обработкой; возникновение гончарства - изготовление толстостенной остродонной глиняной посуды; окончательное оформление животноводства, становление земледелия; приоритетность морского промысла в прибрежных районах;

- поздний неолит - широкое распространение поселения древнего человека на полуострове (побережье, горная часть, степные районы) и тождественность артефактов крымских стоянок с аналогичными памятниками Украины, Нижнего Поволжья, Северного Кавказа как основания предположения о культурных и этнических связях населения указанных территорий; расцвет микролитической вкладышевой техники, усовершенствование плоской и струйной отжимной ретуши; резкое увеличение количества и качества изготовления призматических пластинок; развитие разнообразных резцов на сколах пластинок; вариативность форм гео- метрических микролитов, трапеций со струганой спинкой и сегментов с плоской ретушью по дуге; совершенствование керамического производства (появление разнообразной орнаментировки посуды в виде прочерченных линий, зубчатого штампа, ямок, бороздок, штрихов); доместикация лошади, становление птицеводства (остеологические остатки домашней курицы на стоянке Таш-Аир I и II) [8. С. 144];

- энеолит и ранняя бронза - сходства индустрии и обряда погребения на стоянках Крыма с памятниками Юго-Восточной Европы как свидетельства этнической близости племен указанных территорий; постепенная замена микролитов орудиями двусторонней обработки, созданных путем отжимной и зубчатой техники; появление больших треугольных наконечников стрелдротиков, кинжалов и первых металлических предметов ямно-катакомбного типа; распространение шарообразных и плоскодонных сосудов ручной лепки с ярко выраженной шейкой и разнообразным орнаментом (ёлочный, шнуровой, ямочный, нарезной); животноводство и земледелие как основа хозяйства древнего человека [Там же. С. 144-145].

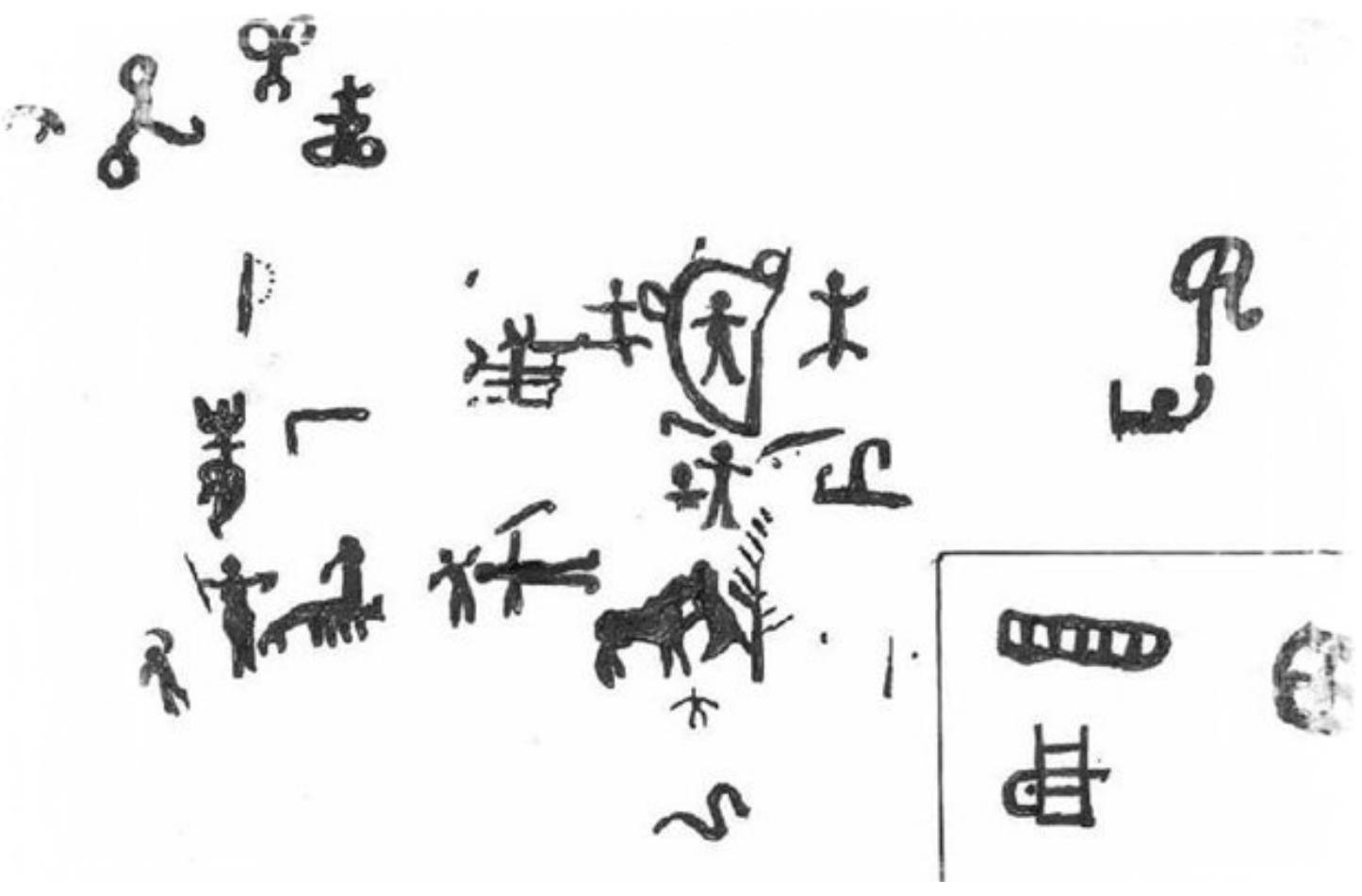

В 1960 г., объединив выводы по исследованиям Таш-Аира I, II и Замиль-Кобы I, II, Д.А. Крайнов вновь акцентировал на раннем возникновении производящего хозяйства в Крыму. Здесь следует отметить, что действительно в мезолите у обитателей крымских навесов и гротов была доместицирована собака, начиналось приручение кабана. В неолите появился домашний бык и, менее вероятно, коза и овца. Но все же число костей домашних животных на открытых археологом стоянках было невелико: преобладающими оставались кости диких животных (благородного оленя, косули, дикого кабана). На выводы ученого в начале 60-х гг. XX в. обратил внимание археолог А.А. Формозов. Ссылаясь на выводы палеонтолога Е.Л. Дмитриевой, изучавшей фаунистические комплексы Таш-Аира II и ЗамильКобы I, II, А.А. Формозов указывал, что остеологические находки стоянок прямо подтверждали факт, что вплоть до ранней бронзы охота оставалась главным средством существования человека в Крыму [10. C. 186].

Кроме этого, по мнению ученого, неподтвержденной оставалась и позиция Д.А. Крайнова о существовании в неолите отгонного животноводства. Как известно, указывал А.А. Формозов, на горные пастбища от- 
гоняли мелкий рогатый скот, кости которого на неолитических стоянках Крыма отсутствуют. Вместе с тем рассуждения об отгоне на яйлу, к примеру свиней (остатков которых в неолите действительно много), являются, безусловно, абсурдными [11. С. 117]. Таким образом, резюмировал А.А. Формозов, о развитии земледелия, кроме единичных косвенных данных (к примеру, находки примитивной мотыги на стоянке Замиль-Коба II), других свидетельств пока не существует [12. C. 25].

При этом, несмотря на указанные сложности и разночтения в интерпретации результатов изучения первобытного памятника, научная ценность стоянки ТашАир I, II состояла как в получении богатых коллекций по истории крымского животноводства, так и в комплексной стратиграфии. В этой связи роль Д.А. Крайнова как первоисследователя оставалась и остается бесспорной.

Еще одним направлением научной деятельности Д.А. Крайнова, основанной в том числе и на крымском материале, были вопросы исторического краеведения. Следует указать, что для краеведческой деятельности 1930-1940-х гг., в отличие от предыдущих этапов, характерными тенденциями стали унификация подходов к изучению исторического прошлого, идеологизация и стандартизация и, соответственно, ограничение самостоятельной деятельности региональных исследовательских центров. В послевоенное время, с конца 1950-х гг., научный статус краеведения был восстановлен. В связи с этим Д.А. Крайнов уделил внимание вопросам развития регионального краеведения, акцентировав на пользе проведения совместных исследований академических и местных экспедиций.

В 1957 г. в статье «Археология и краеведение» ученый, подчеркивая особое значение археологических памятников как единственных источников по изучению древнейшего прошлого, указал на необходимость их охраны по причине влияния комбинации природных, техногенных и антропогенных факторов [13. С. 271272]. Важным для этого, по мнению Д.А. Крайнова, была совместная коллегиальная работа профессиональных археологов и региональных музеев краеведческих обществ и отдельных любителей старины. Археолог сформулировал приоритетные направления, охарактеризовал группы методов краеведческой деятельности. Так, среди основных форм регионального краеведения Д.А. Крайновым были выделены:

- создание Музейных советов (активов из краеведов) при местных музеях города и района, в задачи которых должны были входить «охрана археологических, исторических и архитектурных памятников, учет этих памятников, систематическое наблюдение за объектами земляных работ и строительства с целью выявления, фиксации и сбора ценных археологических материалов»;

- сбор сведений о всех археологических, исторических и архитектурных объектах района или области по итогам изучения научной литературы и музейных фондов с составлением картотеки охранных учетных карточек для отделов культуры по установленному образцу;

- составление постоянно обновляемых списков всех выявленных памятников и нанесение их на карту района, включая выезды на места для предварительного обследования состояния памятника с предоставлением отчетов в региональные отделы культуры, а также - в ИИМК АН СССР (отдел полевых исследований);

- пропаганда и популяризация вопросов охраны памятников (проведение лекций, семинаров, открытых занятий и конференций);

- создание разветвленной сети «членов-корреспондентов» из числа местных краеведов (работников культуры, учителей, школьников, руководителей музеев, исторических, туристических и прочих кружков) для выявления, первичного наблюдения и охраны археологических памятников. Как отмечал Д.А. Крайнов, такая система не только способствует сохранению для науки важных исторических памятников, но и помогает в поиске новых местонахождений [13. С. 273].

Отдельное внимание Д.А. Крайнов уделил характеристике деятельности школьных краеведческих кружков. В этом контексте им были конкретизированы ведущие этапы работы таких институций:

1. Пропедевтический - определение задач и целей, составление плана работы и формулирование основных тем исследований.

2. Теоретический - ознакомление с историей края, лекционная характеристика региональных археологических памятников в комбинации с тематическими экскурсиями, подготовка докладов и сообщений, изучение методики археологической разведки, учета и фиксации археологических объектов (проведение замеров, определение направления по компасу, умение делать глазомерную съемку плана и понимание географической карты, ведение полевого дневника).

3. Практический - организация экскурсии по осмотру и детальной фиксации исследованного археологического памятника в комбинации с этнографическими, зоолого-ботаническими, географическими наблюдениями. Следует отметить, что проведению археологической разведки Д.А. Крайнов придавал важное значение, детально характеризуя каждый шаг ее реализации от сбора сведений у местного населения до описания обнаруженного памятника, предлагая авторскую анкетированную форму.

4. Итоговый - систематизация собранного и обработанного материала (дневников, карт, альбомов с зарисовками, фотоснимков, планов, описей найденных предметов и самих вещей), передача камерально обработанных коллекций в местный краеведческий музей (в самом кружке оставались копии), публикация Отчета о результатах разведки в специальном номере школьной стенгазеты и в местном печатном органе [Там же. С. 274-275].

Таким образом, писал Д.А. Крайнов, краеведческие организации, исходя из специфики региона (Крымско- 
го, Центральной Русской равнины, Северо-Восточной России), должны стать интеграторами и проводниками поисково-исследовательской работы, которая будет способствовать не только комплексному изучению истории края, но и сформирует адекватную последовательную экспозицию этой истории.

В 1959 г. «крымские периоды» исследований Д.А. Крайнова завершились. Ученый встал во главе организованной им Верхневолжской экспедиции Института археологии АН СССР. На протяжении почти 30 лет экспедиция проводила комплексные исследования разновременных памятников (от финального палеолита до конца раннего железного века) на территории Калининской, Ярославской, Ивановской областей. Параллельно археолог приступил к изучению фатьяновских могильников Ивановской области. Через 10 лет, в 1969 г., ключевые выводы по истории фатьяновской культуры были обобщены и представлены Д.А. Крайновым в докторской диссертации «Древнейшая история Волго-Окского междуречья. Фатьяновская культура» и в монографии «Древнейшая история Волго-Окского междуречья: Фатьяновская культура II тыс. до н.э.» [1. С. 98-99]. С начала 60-х и до 90-х гг. ХХ в. Д.А. Крайнов занимался неолитом Центра Русской равнины, проводил раскопки на озере Селигер в Калининской области, Карашском торфянике в Ярославской области, Сахтышских стоянках Ивановской области. Итогом указанной экспедиционной работы и ее теоретического обобщения стало выделение верхневолжской ранненеолитической культуры.

С 1976 г. Д.А. Крайнов работал председателем археологической секции Министерства культуры РСФСР, ученым секретарем и председателем Комитета по изучению закономерностей развития человеческих обществ, созданного по инициативе Отделения общественных наук АН СССР, был членом четвертичной комиссии по изучению ископаемого человека.
Полевая археологическая деятельность ученого завершилась в 1992 г., когда Дмитрию Александровичу было 88 лет. Умер Д.А. Крайнов 8 ноября 1998 г. в день Димитрия Солоунского, святого, которого считал своим покровителем, и был похоронен на Хованском кладбище Москвы [2].

Таким образом, в творчески продолжительной и научно богатой биографии ученого можно выделить два периода крымских исследований. Первый относится к 1935-1941 гг. и условно может быть назван полевым. Его характерными содержательными особенностями стали открытие в горной и предгорной части полуострова серии первобытных стоянок, характеризующихся наличием сложной стратиграфии и собранными богатыми коллекциями артефактов; поиски на верхнепалеолитических стоянках Крыма остатков неандертальского человека; обнаружение на полуострове первых погребенных стоянок эпохи мустье. Второй период, академический, включающий 19551957 гг., ознаменовался систематизацией археологического материала и анализом коллекций, собранных в предыдущий; изданием научных монографий и серии публикаций по крымской тематике (в том числе посвященных стоянкам Таш-Аир I, II и Замиль-Коба I, II); созданием авторской периодизации крымских памятников доисторического периода; выделением этапов генезиса производящих форм хозяйства у первобытного человека; актуализацией вопросов развития отечественного краеведения.

Благодаря плодотворной археологической работе Д.А. Крайнова для следующих поколений ученых были открыты новые археологические памятники Крыма, дообследованы, заново пересмотрены и уточнены выводы по уже известным первобытным стоянкам, затронуты и сформулированы дискуссионные вопросы, актуальные для современных исследователей каменного века Крыма, Кавказа и Северного Причерноморья.

\section{ЛИТЕРАТУРА}

1. Черкасов О.В. Первісні стоянки Криму та їх дослідники (кінець ХІХ - перша половина ХХ ст.): Наукове видання. Севастополь ; Ялта : Державний морський університет імені адмірала Ф.Ф Ушакова, 2013. 137 с.

2. Леонова Е.В., Костылева Е.Л., Жилин М.Г. и др. Д.А. Крайнов: археолог и человек. URL: http://hyperlib.libfl.ru/persons/6856.html.

3. Крайнов Д.А. Новые мустьерские стоянки Крыма и Кавказа // Бюллетень комиссии по изучению четвертичного периода. 1947. Т. 9. С. 2335.

4. Замятнин С.Н. Очерки по палеолиту. М.; Л. : АН СССР, 1961. 176 с.

5. Формозов А.А. Мустьерская стоянка Кабази в Крыму (первый опыт изучения погребенных пещер в СССР) // Советская археология. 1959. Вып. 29-30. С. 143-158.

6. Черкасов А.В. Первые погребённые стоянки в Крыму: к истории изучения // Современные тенденции развития науки и технологий : сб. науч. трудов по материалам IV Междунар. науч.-практ. конф. 31.07.2015 г. : в 6 ч. / под общ. ред. Е.П. Ткачевой. Белгород : ИП Ткачева Е.П., 2015. Ч. III. С. 78-80.

7. Крайнов Д.А. Пещерная стоянка Замиль-Коба I // Труды Государственного исторического музея. 1938. № 1, вып. VIII. С. 8-32.

8. Крайнов Д.А. Пещерная стоянка Таш-Аир I как основа периодизации послепалеолитических культур Крыма // Материалы и исследования по археологии СССР. 1960. № 91. 192 с.: ил.

9. Шульц П.Н. Работы Тавро-Скифской экспедиции (1945-1946 годы) // Памятники искусства. Бюллетень ДМІІ. 1947. Вып. 2. С. 29.

10. Дмитриева Е.Л. Фауна крымских стоянок Замиль-Коба II и Таш-Аир II // Материалы и исследования по археологии СССР (МИА). М. ; Л. : АН СССР, 1960. № 91. С. 186.

11. Формозов А.А. Неолит Крыма и Черноморского побережья Кавказа (Материалы к изучению неолита Юга СССР) // Материалы и исследования по археологии СССР. 1962. № 102. С. 89-123.

12. Археология. Неолит Северной Евразии (отв. ред. Ошибкина С.В.). М. : Наука, 1996. 379 с.

13. Крайнов Д.А. Археология и краеведение // Советская археология. 1957. № 2. С. 270-275. 
Cherkasov Aleksey V., Sevastopol Branch of Admiral Ushakov state maritime university (Sevastopol, Russia). lakets2006@meta.ua D.A. KRAYNOV AS THE RESEARCHER OF THE STONE AGE OF CRIMEA

Keywords: primeval history of the Crimea, the periodization of primitive cultures, primitive settlement, an archaeological monument, the historiography of the study of the stone age, the personalities of the academic, historical study of local lore.

The aim of the presented article is a historiography analysis of creative heritage of Russian scientist, archaeologist D.A. Kraynov sanctified to the questions of primitive history of Crimea. To reach the aim of the study the following tasks were set: selection from biography of scientist of the Crimean periods of expeditionary and scientific activity with their subsequent description; analytical interpretation of publications of D.A. Kraynov, which were written on the Crimean materials related to the Stone age period of Crimea; specification of the value of Crimean researches of D.A. Kraynov for national and regional archaeological science. Research methodology is based on complex application of the following scientific principles: historical method, objectivity, comparatively-historical approach, retrospection etc. The problem field of the study includes the following components: the establishment of continuity in the history of the study of the primitive past of the Crimean Peninsula, for example, the specific identity of the scientist and the objective of ascertaining the contribution of the historian, his works in the formation and development of national historiography. Source base for the study were, primarily, the works of D.A. Kraynov on archeology and history of Crimea of the Stone age, and modern publications devoted to the life and work of the scientist (as in generalizing works on the history of archaeological thought in Russia and separate articles, essays, memoirs). In the process of undertaken a study the authors distinguished two periods of Crimean researches of scientist. First, expeditionary, relates to 1935-1941. Its informative features were the discovery by D.A. Kraynov in the mountainous part of the Peninsula a series of prehistoric sites, which were characterized by the presence of complex stratigraphy and rich collections of artifacts; the search sites of the upper Paleolithic of the Crimea, the remnants of the Neanderthal man; the discovery of the first in the region buried sites of the Paleolithic era; clarifying the specifics of the archaeological monuments of the primitive history of the Crimea and the formulation of guidelines for the methods of their excavation. For example, studies of small squares in layers, preserving between them the control jumpers; detailed description of each of the artifacts found with his further interpretation and typology. The second period, "academic", included 1955-1957, was characterized by systematization of archaeological material and analysis of the collections gathered by a scientist in a pre-war period; by edition of scientific monographs and series of publications on the Crimean subjects (including, sanctified to the stands of Tash-air I, II and Zamil'-Koba I, II); by creation of authorial division into periods of the Crimean monuments of prehistoric period; by the selection of the stages of genesis of productive forms of economy for a primitive man; by actualization of questions of development of regional study of a particular region.

\section{REFERENCES}

1. Cherkasov, O.V. (2013) Pervisni stoyanki Krimu ta ïkh doslidniki (kinets' XIX - persha polovina XX st.) [Primitive encampments in Crimea and their researchers (the late 19th - early 20th centuries)]. Sevastopol, Yalta: Admiral F.F. Ushakov State Maritime University.

2. Leonova, E.V., Kostyleva, E.L., Zhilin, M.G. et al. (n.d.) D.A. Kraynov: arkheolog i chelovek [D.A. Krainov: Archaeologist and person]. [Online] Available from: http://hyperlib.libfl.ru/persons/6856.html.

3. Kraynov, D.A. (1947) Novye must'erskie stoyanki Kryma i Kavkaza [New Mousterian camps of the Crimea and the Caucasus]. Byulleten' komissii po izucheniyu chetvertichnogo perioda. 9. pp. 23-35.

4. Zamyatnin, S.N. (1961) Ocherki po paleolitu [Essays on the Paleolith]. Moscow; Leningrad: USSR AS.

5. Formozov, A.A. (1959) Must'erskaya stoyanka Kabazi v Krymu (pervyy opyt izucheniya pogrebennykh peshcher v SSSR) [Kabazi Mousterian camps in the Crimea (the first experience of studying buried caves in the USSR)]. Sovetskaya arkheologiya. 29-30. pp. 143-158.

6. Cherkasov, A.V. (2015) Pervye pogrebennye stoyanki v Krymu: k istorii izucheniya [The first burial camps in the Crimea: To the history of the study]. In: Tkacheva, E.P. (ed.) Sovremennye tendentsii razvitiya nauki i tekhnologiy [Modern trends in the development of science and technology]. Belgorod: Tkacheva E.P. pp. 78-80.

7. Kraynov, D.A. (1938) Peshchernaya stoyanka Zamil'-Koba I [Zamil-Koba I cave camp]. Trudy Gosudarstvennogo istoricheskogo muzeya. 1(8). pp. 832.

8. Kraynov, D.A. (1960) Peshchernaya stoyanka Tash-Air I kak osnova periodizatsii poslepaleoliticheskikh kul'tur Kryma [The cave camp Tash-Air I as a basis for the periodization of the Crimean post-Palaeolithic cultures]. Materialy i issledovaniya po arkheologii. 91.

9. Shultz, P.N. (1947) Raboty Tavro-Skifskoy ekspeditsii (1945-1946 gody) [Works of the Tavro-Scythian expedition (1945-1946)]. Pamyatniki iskusstva. Byulleten' DMII. 2. pp. 29.

10. Dmitrieva, E.L. (1960) Fauna krymskikh stoyanok Zamil'-Koba II i Tash-Air II [The fauna of the Crimean camp Zamil-Koba II and Tash-Air II]. Materialy i issledovaniya po arkheologii SSSR (MIA). 91.

11. Formozov, A.A. (1962) Neolit Kryma i Chernomorskogo poberezh'ya Kavkaza (Materialy k izucheniyu neolita Yuga SSSR) [Neolithic of the Crimea and the Black Sea coast of the Caucasus (Materials for the study of the Neolithic of the South of the USSR)]. Materialy $i$ issledovaniya po arkheologii SSSR. 102. pp. 89-123

12. Oshibkin, S.V. (ed.) (1996) Arkheologiya. Neolit Severnoy Evrazii [Archeology. Neolithic of Northern Eurasia]. Moscow: Nauka.

13. Kraynov, D.A. (1957) Arkheologiya i kraevedenie [Archeology and Local History]. Sovetskaya arkheologiya. 2. pp. $270-275$. 